\title{
HUBUNGAN INTAKE CAIRAN DENGAN TEKANAN DARAH PADA PASIEN GAGAL GINJAL KRONIK (GGK) YANG MENJALANI HEMODIALISA
}

\author{
Fitri Mailania ${ }^{a}$, Ginza Johanda ${ }^{a}$ \\ ${ }^{a}$ STIKes YPAK Padang, Jln. S.Parman No. 120 Lolong Padang, 25137, Indonesia \\ e-mail korespondensi : fitri_mailani@ymail.com
}

\begin{abstract}
Excessive fluid intake in patients with chronic kidney failure will cause complications that lead to death. This study aims to determine the relationship between fluid intake and blood pressure in patients with chronic renal failure undergoing hemodialysis at Rs. Tk III Dr. Reksodiwiryo Padang. This type of research was descriptive correlation, with a sample of 49 respondents taken by consecutive sampling technique. Data collection and research was carried out on March 15 to July 4, 2018. The method of collecting data with observation sheets and questionnaires. Univariate analysis was carried out by presenting data in the form of the mean, standard deviation, minimum, and maximum while bivariate analysis used a correlation test with Rank Spearman. The results of the univariate study of Sistole Blood Pressure from 49 patients obtained a minimum value of $0 \mathrm{mmHg}$, and the maximum value was $60 \mathrm{mmHg}$, the standard deviation was 12.69, the mean value was $16.33 \mathrm{mmHg}$. Whereas in the Diastole Blood Pressure the minimum value is -20mmHg (reduced by 20mm $\mathrm{Hg}$ ), and the maximum value is 30, the mean value is $9.18 \mathrm{mmHg}$. The fluid intake minimum value is $825.7 \mathrm{ml}$, maximum is $2216.7 \mathrm{ml}$, and mean is $882 \mathrm{ml}$. Bivariate results showed that there was a relationship between fluid intake and systolic blood pressure $(p=0.032)$ and diastolic blood pressure $(p=0,013)$. It is hoped that collaboration between patients, families and nurses in monitoring the patient's fluid intake to prevent complications due to fluid buildup.
\end{abstract}

Keywords: Hemodialysis, fluid intake, blood pressure

\begin{abstract}
Abstrak
Intake cairan yang berlebih pada pasien gagal ginjal kronik akan menyebabkan komplikasi yang berujung kepada kematian. Penelitian ini bertujuan untuk mengetahui hubungan intake cairan dengan tekanan darah pada pasien gagal ginjal kronik yang menjalani hemodialisa di Rs. Tk. III Dr. Reksodiwiryo Padang. Jenis penelitian ini adalah deskriptif korelasi, dengan sampel sebanyak 49 responden yang diambil dengan teknik consecutive sampling. Pengumpulan data dan Penelitian dilakukan pada bulan 15 Maret sampai 4 Juli 2018. Cara pengumpulan data dengan lembar observasi dan kuisioner. Analisis univariat dilakukan dengan menyajikan data dalam bentuk mean, standar deviasi,minimum,dan maksimum sedangkan analisis bivariat menggunakan uji korelasi dengan Rank Spearman's. Hasil penelitian univariat Tekanan Darah Sistole dari 49 pasien didapatkan nilai minimum adalah $0 \mathrm{mmHg}$, dan nilai maksimum adalah $60 \mathrm{mmHg}$, standar deviasi adalah 12,69, nilai mean $16,33 \mathrm{mmHg}$. Sedangkan pada Tekanan Darah Diastole nilai minimum adalah -20mmHg (berkurang 20mmHg), dan nilai maksimum adalah $30 \mathrm{mmHg}$, nilai mean $9,18 \mathrm{mmHg}$. Intake cairan nilai minimum $825,7 \mathrm{ml}$, maksimum $2216,7 \mathrm{ml}$, dan mean $882 \mathrm{ml}$. Hasil bivariat menunjukkan bahwa ada hubungan intake cairan dengan tekanan darah sistole $(p=0,032)$ dan diastole $(p=0,013)$. Diharapkan kerjasama antara pasien, keluarga dan perawat dalam pemantauan intake cairan pasien untuk mencegah komplikasi akibat penumpukan cairan.
\end{abstract}

Kata Kunci : hemodialisa, intake cairan, tekanan darah.

\section{PENDAHULUAN}

Gagal ginjal Kronik (GGK) adalah suatu sindroma klinik yang disebabkan oleh penurunan fungsi ginjal yang bersifat menahun, berlangsung progresif dan irreversible. Kerusakan ginjal ini mengakibatkan masalah pada kemampuan dan kekuatan tubuh yang menyebabkan aktivitas kerja terganggu, tubuh jadi mudah lelah dan lemas sehingga kualitas hidup pasien menurun (Smeltzer \& Bare, 2008). Badan Kesehatan Dunia atau World Health Organization (WHO) menyebutkan pertumbuhan penderita gagal ginjal pada tahun 2013 telah meningkat $50 \%$ dari tahun sebelumnya. Menurut National Kidney Foundation tahun 2015, $10 \%$ penduduk didunia menderita Gagal Ginjal Kronik (GGK) dan terdapat 2 juta 
penderita GGK yang melakukan terapi pengganti ginjal berupa dialisis dan transplantasi ginjal. Sedangkan 1 juta penderita meninggal setiap tahun karena tidak mempunyai akses untuk pengobatan. Menurut United States Data System (USRDS) tahun 2014, penduduk Amerika yang terdiagnosa GGK dai stage 1-5 sebanyak $14,8 \%$ dari seluruh penduduk Amerika. Mortalitas pasien GGK penduduk Amerika yang menjalani pengobatan adalah 111,2 per 1000 pasien dalam setahun. Sedangkan pada tahap End Stage Renal Disease (ESRD) adalah sebanyak 120.688 orang (National Kidney Foundation, 2016 dalam Soraya 2017).

Berdasarkan Data Riset Kesehatan

Dasar (Riskesdas) Indonesia tahun 2013, penderita GGK di Indonesia mencapai $0,2 \%$ dari seluruh penyakit di Indonesia. Selain itu, GGK di Indonesia menempati urutan kedua setelah penyakit jantung, dengan pertumbuhan hampir $100 \%$ dalam kurun waktu 2014-2015. (Riskesdas, 2013 dalam Soraya 2017).

Menurut data dari Perhimpunan Nefrologi Indonesia (PERNEFRI) tahun 2014, jumlah pasien yang harus menjalani Hemodialisis (HD) di Indonesia adalah 17.192 dan pasien aktif yang masih menjalani terapi HD pada tahun 2014 adalah 11.689. Sedangkan prevalensi gagal ginjal kronik di Provinsi Sumatera Barat $0,2 \%$ dari penduduk dari pasien gagal ginjal kronis di Indonesia, yang mencakup pasien mengalami pengobatan, terapi penggantian ginjal, dialysis peritonial dan Hemodialisis pada tahun 2013 (Dinkes, 2013). Berdasarkan hasil data rekam medis keperawatan ruangan unit hemodialisa Rumah Sakit Tk. III Dr. Reksodiwiryo Padang tahun 2017 didapatkan prevalensi pasien Gagal Ginjal Kronik tahun 2017 tercatat sebanyak 487 pasien. April 2018 terdapat 49 pasien.

Menjaga intake cairan pada tubuh pasien Hemodialisis (HD) dapat dilihat dari perilaku pembatasan cairan pasien tersebut. Perilaku pembatasan intake cairan yaitu menjaga intake natrium, kalium, fosfor, dan protein, serta jumlah cairan yang diminum dan makanan yang mengandung banyak air. Namun, kemampuan perawatan mandiri pengelolaan cairan pada pasien GGK yang menjalani HD masih rendah. Pasien merasa tidak sanggup membatasi minumnya, salah satunya adalah pasien susah melakukan penggunaan es batu sebagai pengganti air untuk mengurangi rasa haus (Haryono, 2013). Pembatasan cairan sering kali sulit dilakukan oleh pasien, terutama jika mereka mengkonsumsi obat-obatan yang membuat membran mukosa kering seperti diuretik. Karena obat tersebut akan menyebabkan rasa haus yang berakibat adanya respon untuk minum (Potter \& Perry, 2008).

Faktor-faktor yang mempengaruhi kepatuhan pembatasan asupan cairan pada pasien gagal ginjal kronik yang menjalani hemodialisa adalah pengetahuan, dukungan keluarga dan Interdyalitic Weight Gain (IDWG). Menurut Hadi \& Wantonoro (2015) terdapat hubungan antara lama menjalani hemodialisis dengan kepatuhan pembatasan cairan pada pasien gagal ginjal kronik di RS PKU Muhamadiyah unit II Yogyakarta.

Menurut Lolyta (2011) faktor yang mempengaruhi tekanan darah hemodialisis pada pasien gagal ginjal kronik di RS Telogorejo Semarang adalah riwayat keluarga,diet, dan Interdyalitic Weight Gain (IDWG). Menurut Istanti (2014) IDWG berhubungan sangat erat dengan masukan cairan pada pasien gagal ginjal. Hal ini dibuktikan melalui penelitian Osharandi dkk (2013) bahwa pendidikan kesehatan terkait asupan cairan pada kelompok kecil pasien yang menjalani hemodialisa dapat menurunkan berat badan interdialitik dan tekanan darah sistole. Hasil penelitian Fatmawati, I (2016) menyatakan bahwa $100 \%$ pasien mengalami perubahan tekanan darah 
sistole dan $74,2 \%$ pasien mengalami perubahan tekanan darah diastole pada pasien Gagal Ginjal Kronik yang menjalani Hemodialisa di RSUD Sukoharjo.

Berdasarkan hasil penelitian yang dilakukan oleh Mailani (2014) di RSUD dr.Pirngadi dan RSUP Haji Adam Malik Medan tahun 2014 menunjukkan bahwa pasien gagal ginjal kronik yang menjalani hemodialisa mengalami penambahan berat badan adalah 3,97\% (rentang 0,45\%$8,19 \%$ ). Rata-rata penambahan berat badan interdialisis responden termasuk kategori berat karena $>3,9 \%$. Hasil penelitian Fatmawati, I (2016) mengenai hubungan asupan natrium dengan tekanan darah pasien GGK menunjukkan bahwa tidak ada hubungan asupan natrium dengan tekanan darah pasien.

Berdasarkan survey awal yang dilakukan di Rumah Sakit Tk. III Dr. Reksodiwiryo terhadap 10 Pasien didapatkan hasil bahwa 8 responden mengalami peningkatan tekanan darah dibandingkan dengan post Hemodialisa yang lalu sedangkan 2 diantaranya tidak mengalami peningkatan tekanan darah. Berdasarkan banyak nya fenomena yang ditemukan dan penelitian terdahulu yang dilakukan maka peneliti tertarik melakukan penelitian tentang intake cairan dan tekanan darah pasien GGK. Adapun tujuan dari penelitian ini adalah untuk mengetahui hubungan intake cairan dengan tekanan darah pada pasien gagal ginjal kronik yang menjalani hemodialisa di Rumah Sakit Tk. III Reksodiwiryo Padang tahun 2018.

\section{METODE PENELITIAN}

Penelitian menggunakan desain deskriptif korelasi, yang dilakukan di Rumah Sakit Tk. III Dr. Reksodiwiryo Padang di unit Hemodialisa. Waktu pengambilan data dan penelitian dilakukan mulai pada tanggal 15 Maret sampai 4 Juli 2018. Populasi dari penelitian ini yaitu diambil dari 1 bulan terakhir yaitu pada bulan April sebanyak 49 pasien. Teknik pengambilan sampel yaitu consecutive sampling.

Pengambilan data diawali dengan peneliti memilih responden dengan kriteria kesadaran compos mentis, sedang menjalani terapi hemodialisis dua kali seminggu. Selanjutnya memberikan lembar observasi dan pemberian gelas ukur (satuan ml) untuk mengukur intake cairan selama 2 hari setelah hemodialisis dilakukan. Sekaligus dilakukan pengukuran tekanan darah dengan menggunakan sphygmomanometer air raksa pada saat post hemodilisis dan pre hemodialisis berikutnya lalu dicatat dilembar observasi. Data dianalisis menggunakan analisis univariat berupa nilai mean, standar deviasi, minimum dan maksimum. Sedangkan analisis bivariat uji non parametrik yaitu uji korelasi spearman.

\section{HASIL PENELITIAN \\ Analisa Univariat}

\section{a. Karakteristik responden}

Dari 49 pasien hasil penelitian karakteristik responden didapatkan bahwa mayoritas rata-rata pasien berusia 36-45 tahun yaitu 23 pasien $(46,9 \%)$, mayoritas berjenis kelamin laki-laki yaitu 25 orang $(51,02 \%)$, Mayoritas pekerjaan terbanyak adalah IRT dengan 14 pasien $(28,5 \%)$, Mayoritas pendidikan terakhir pasien adalah sekolah menengah yaitu 29 pasien $(59,1 \%$, mayoritas lama menjalankan HD $>3$ bulan sebanyak 42 pasien $(85,71 \%)$, mayoritas berat badan (BB) yang terjadi dengan rata-rata berat badan $40-50 \mathrm{~kg}$ sebanyak 20 pasien $(40,8 \%)$.

b. Tekanan Darah Sistole dan Diastole Tabel 1. Gambaran perubahan tekanan darah sistole dan diastole pasien gagal ginjal kronik yang menjalani hemodialisa

\begin{tabular}{llllll}
\hline Variabel N Min & Maks & $\begin{array}{l}\text { Std } \\
\text { Devia }\end{array}$ & Mean \\
\hline
\end{tabular}




\begin{tabular}{llllll}
\hline & & \multicolumn{3}{l}{$\boldsymbol{s i}$} \\
\hline Sistole & 49 & 0 & 60 & 12.69 & 16.33 \\
\hline Diastole & 49 & -20 & 30 & 11.87 & 9.18 \\
\hline
\end{tabular}

Tabel 3. Distribusi Responden berdasarkan Kategori Perubahan Tekanan Darah Diastole

\begin{tabular}{lll}
\hline $\begin{array}{l}\text { Tekanan Darah } \\
\text { diastole }\end{array}$ & Jumlah & $\begin{array}{l}\text { Persentase } \\
(\%)\end{array}$ \\
\hline Perubahan + & 34 & 69 \\
\hline Perubahan - & 15 & 31 \\
\hline
\end{tabular}
pada perubahan Tekanan Darah Sistole dari 49 pasien didapatkan nilai minimum adalah $0 \mathrm{mmHg}$, dan nilai maksimum adalah $60 \mathrm{mmHg}$, standar deviasi adalah $12.69 \mathrm{mmHg}$, nilai mean $16,33 \mathrm{mmHg}$. Sedangkan perubahan pada Tekanan Darah Diastole dari 49 pasien didapatkan nilai minimum adalah $-20 \mathrm{mmHg}$, dan nilai maksimum adalah $30 \mathrm{mmHg}$, standar deviasi adalah $11.87 \mathrm{mmHg}$ dan nilai mean $9.18 \mathrm{mmHg}$.

Data perubahan tekanan darah sistole/ diastole kemudian dikategorikan menjadi dua yaitu berubah + (jika terdapat peningkatan nilai sistole/diastole responden dari pasca hemodialisis, dimana tekanan darah diukur kembali sebelum menjalani hemodialisis pada periode berikutnya), dan yang kedua berubah - (jika nilai

Dari tabel 3 dapat dilihat bahwa 34 responden mengalami peningkatan tekanan darah diastole dan 15 responden tidak mengalami perubahan tekanan darah diastole atau terjadi penurunan tekanan darah diastole.

c. Intake Cairan

Tabel 4.'Gambaran Intake Cairan Pada Pasien Gagal Ginjal sistole/diastole konstan atau terdapat penurunan nilai sistole/diastole responden pasca hemodialisis, dimana tekanan darah diukur kembali sebelum menjalani hemodialisis pada periode berikutnya). Berikut ini adalah tabel distribusi frekuensi responden berdasarkan perubahan tekanan darah sistole dan diastole.

\section{Tabel 2. Distribusi Responden berdasarkan Kategori Perubahan Tekanan Darah Sistole.}

\begin{tabular}{llc}
\hline $\begin{array}{l}\text { Tekanan } \\
\text { Darah Sistole }\end{array}$ & Jumlah & \multicolumn{1}{c}{$\begin{array}{l}\text { Persentase } \\
(\%)\end{array}$} \\
\hline Perubahan + & 45 & 92 \\
\hline Perubahan - & 4 & 8 \\
\hline Dari tabel 2 & dapat dilihat bahwa 45 \\
responden mengalami peningkatan tekanan \\
darah sistole dan 4 responden tidak \\
mengalami perubahan tekanan darah \\
sistole atau terjadi penurunan tekanan \\
darah sistole.
\end{tabular}

\begin{tabular}{|c|c|c|c|c|c|}
\hline Variabel & $\mathbf{N}$ & Mean & $\begin{array}{l}\text { Std } \\
\text { deviasi }\end{array}$ & Min & Mak \\
\hline $\begin{array}{l}\text { Intake } \\
\text { Makan/minum } \\
\text { Obat-obatan } \\
\text { Air metabolism }\end{array}$ & 49 & $\begin{array}{l}1878,1 \\
0,96 \\
285,7\end{array}$ & $\begin{array}{l}296,4 \\
1,7 \\
42,943\end{array}$ & $\begin{array}{l}1375 \\
0 \\
202\end{array}$ & $\begin{array}{l}2800 \\
7 \\
375\end{array}$ \\
\hline $\begin{array}{l}\text { Rata-rata } \\
\text { Intake }\end{array}$ & 49 & 882 & 3475 & 825.7 & $\begin{array}{l}2216 . \\
6\end{array}$ \\
\hline
\end{tabular}

Berdasarkan tabel 4 dapat dilihat bahwa intake cairan dari 49 pasien seperti intake makan/minum didapatkan nilai mean adalah 1878,1, standar deviasi adalah 296,4, nilai minimum adalah 1375 , dan nilai maksimum adalah 2800. Intake cairan obat-obatan/infuse didapatkan nilai mean adalah 0,96, standar deviasi adalah 1,7, nilai minimum adalah 0 , dan nilai maksimum adalah 7. Intake cairan air metabolisme didapatkan nilai mean adalah 285,7, standar deviasi adalah 42,9, nilai minimum adalah 202, dan nilai maksimum adalah 375. Sedangkan rata-rata intake nilai mean 2216.6, nilai standar deviasi 825.7, nilai minimum 882 dan nilai maksimum 3475 (semua perhitungan intake dalam mililiter ( $\mathrm{ml})$.

\section{Analisa Bivariat}

Hubungan Intake Cairan Dengan Tekanan Darah (Sistole dan diastole) 
Untuk melihat korelasi antara intake cairan dan tekanan darah (Sistole dan diastole) dilakukan uji spearman tes.

Tabel 5 Nilai Spearman Test Untuk Melihat Hubungan Intake Cairan Dengan Peningkatan Tekanan Darah Sistole

\begin{tabular}{llll}
\hline Variabel & Mean & SD & P value \\
\hline Intake Cairan & 882 & 3475 & $p=0,032$ \\
$\begin{array}{llll}\text { Tekanan } \\
\text { darah sistole }\end{array}$ & 16.33 & 1269 & \\
\hline
\end{tabular}

*uji rank spearman

Berdasarkan tabel 5 dapat dilihat hasil uji spearman test hubungan intake cairan dengan peningkatan tekanan darah sistole nilai $p=0,032$ (nilai $p<0.5$ ) maka dapat disimpulkan adanya hubungan intake cairan dengan tekanan darah sistole.

Tabel 6 Nilai Spearman Test Untuk Melihat Hubungan Intake Cairan Dengan Peningkatan Tekanan Darah Diastole

\begin{tabular}{llll}
\hline Variabel & Mean & SD & P value \\
\cline { 1 - 3 } Intake Cairan & 882 & 3475 & $p=0,013$ \\
\cline { 1 - 2 } $\begin{array}{l}\text { Tekanan } \\
\text { darah }\end{array}$ & 9.18 & 11,87 & \\
Diastole & & & \\
\hline
\end{tabular}

*uji rank spearman

Berdasarkan tabel 6 didapat hasil uji spearman test hubungan intake cairan dengan peningkatan tekanan darah diastole nilai $p=0.013$, maka dapat disimpulkan adanya hubungan antara intake cairan dengan peningkatan tekanan darah diastole.

\section{PEMBAHASAN}

Tekanan Darah
Peningkatan tekanan darah sistole maupun diastole akibat Gagal Ginjal Kronik dikarenakan penurunan aliran darah ke ginjal serta Laju Filtrasi Glomerulus (LFG) yang berkurang sehingga meningkatkan sistem Renin Angiotensin Aldosteron (RAA). Sel apartus jukstaglomerulus mensekresi enzim renin yang dapat merubah angiotensinogen yang berasal dari hati menjadi Angiotensin I kemudian diubah menjadi Angiotensin II oleh Angiotensin Converting Enzyme (ACE). Angiotensin II dapat menyebabkan vasokontriksi pembuluh darah tepi dan menyebabkan peningkatan tekanan darah (Cianci et al, 2009).

Angiotensin II juga merangsang aldosteron yang dapat meningkatkan retensi air dan natrium $(\mathrm{Na})$ di tubulus ginjal dan menyebabkan tekanan darah meningkat. Pasien Gagal Ginjal Kronik juga mengalami hipervolemia akibat retensi air dan natrium sehingga terjadi peningkatan reabsorbsi natrium di duktus koligentes karena adanya resistensi relatif terhadap hormon natriuretik peptida dan peningkatan aktivitas pompa Na-KATPase di duktus koligentes yang mengakibatkan curah jantung meningkat sehingga menyebabkan peningkatan tekanan darah. Peningkatan aktivitas aldosteron dapat memperberat hipervolemia yang terjadi (Cianci et al, 2009).

Hasil penelitian ini menunjukkan bahwa secara umum akan terjadinya peningkatan tekanan darah pada pasien setelah mengalami gagal ginjal kronik. Hal ini sama dengan penelitian Ferdi, R (2015) dengan judul Perubahan Tekanan Darah Pada Pasien Gagal Ginjal Kronik Sebelum Dan Setelah Menjalani Tindakan Hemodialisis Di Ruang Hemodialisa RSUD Dr. Ibnu Sutowo Baturaja menyatakan bahwa tekanan darah pasien gagal ginjal kronis sebelum dilakukan hemodialisis (pre test) nilai rerata sistole 
adalah $139.74 \mathrm{mmHg}$ sedangkan nilai rerata diastole adalah $80,51 \mathrm{mmHg}$. Dan perubahan tekanan darah pasien gagal ginjal kronis setelah dilakukan tindakan hemodialisis (post test) nilai rerata tekanan darah sistole $155,90 \mathrm{mmHg}$ sedangkan diastole $81,28 \mathrm{mmHg}$.

Hasil penelitian ini juga sejalan dengan penelitian Fatmawati, I (2016) menunjukkan bahwa $100 \%$ pasien mengalami perubahan tekanan darah sistole dan $74,2 \%$ pasien mengalami perubahan tekanan darah diastole.

\section{Intake cairan}

Rata-rata intake cairan pasien adalah $2216.6 \mathrm{ml}$, nilai standar deviasi 825.7, nilai minimum $882 \mathrm{ml}$ dan nilai maksimum $3475 \mathrm{ml}$. Hasil penelitian Lopez-Gomez (2005) menunjukkan bahwa untuk mengurangi komplikasi akibat penyakit ginjal kronik, berat badan interdialisis pasien tidak boleh lebih dari $3,5-4 \%$ berat badan kering.

Hasil penelitian menunjukkan bahwa angka intake cairan dari konsumsi makanan dan minuman yang paling tinggi yaitu rata-rata $882 \mathrm{ml} / 24$ jam. Hal ini dikarenakan respoden tidak mampu mengatasi rasa haus dan keinginan untuk minum. Pemahaman dan kemampuan pasien untuk mengatur pemasukan cairan yang mendekati kebutuhan cairan tubuh diperlukan untuk menghindari akibat kelebihan cairan. Banyak cairan yang dikonsumsi oleh pasien kadang kala bukan karena rasa haus tetapi untuk membantu pasien dalam menelan makanan atau menelan obat (Abuelo, 1999).

Beberapa faktor spesifik yang mempengaruhi penambahan berat badan interdialisis antara lain faktor dari pasien itu sendiri dan beberapa faktor psikososial antara lain faktor demografi, masukan cairan, rasa haus, social support, self efficacy dan stress (Sonnier, 2000). Kelebihan cairan tubuh yang terjadi pada pasien juga sangat terkait dengan kepatuhan pasien hemodialisis itu sendiri.
Kepatuhan merupakan bagian terpenting untuk mengontrol masukan cairan pada pasien yang menjalani hemodialisis, penelitian yang dilakukan oleh Marantika (2014) untuk melihat gambaran kepatuhan pasien yang menjalani hemodialisis di RSUP Haji Adam Malik Medan menyatakan bahwa jumlah pasien yang tidak mematuhi anjuran lebih banyak dibandingkan dengan pasien yang mematuhi anjuran medis.

Jenis kelamin akan mempengaruhi cairan dan berat badan seseorang karena perbedaan komposisi tubuh, tubuh laki-laki yang terdiri dari 55\% air sedangkan perempuan terdiri dari $47 \%$ air (Guyton, 2006). Hal yang sama juga diungkapkan oleh Igbokwe dan Obika (2007) dalam penelitiannya yang menyatakan bahwa laki-laki kurang dapat mengontrol rasa haus, dan rasa haus laki-laki cenderung lebih tinggi jika dibandingkan oleh perempuan, dikarenakan kebutuhan cairan yang lebih tinggi pada laki-laki dan komposisi air yang lebih tinggi.

Asupan cairan harian yang dianjurkan pada pasien yang menjalani hemodialisis adalah dibatasi hanya sebanyak insensible water losses ditambah jumlah urin (Smeltzer \& Bare, 2008). Rasa haus juga dipengaruhi oleh kondisi cuaca (Sarkar et al, 2006).

\section{Hubungan Intake Cairan dengan tekanan darah pasien Gagal Ginjal Kronik yang menjalani Hemodialisa}

Hasil penelitian menunjukkan adanya hubungan intake cairan dengan tekanan darah pasien Gagal Ginjal Kronik yang menjalanini hemodialisa, baik itu tekanan darah sistole maupun diastole. Terjadinya perubahan tekanan darah tersebut cenderung berubah positif (+) yang artinya terjadi peningkatan tekanan darah pada periode dialisis. Tekanan darah responden ketika diukur sebelum melakukan hemodialisis cenderung meningkat dibandingkan dengan tekanan darah pasca hemodialisis pada periode sebelumnya. 
Hal ini bisa disebabkan banyak hal salah satu nya adalah intake cairan yang berlebihan pada periode dialisis.

Penelitian yang dilakukan oleh Istanti (2014) menunjukkan bahwa adanya hubungan antara intake cairan dengan interdialityc weight gain (IDWG) Pada pasien Gagal Ginjal Kronik. Kondisi berat badan yang menggambarkan status cairan pasien yaitu, menjadi salah satu faktor pada komplikasi hemodialisis. Semakin tinggi berat badan interdialisis maka semakin tinggi pula tekanan darah sistole yang berpengaruh pada kejadian hipertensi. Selain itu, pasien dengan kenaikan berat badan interdialisis $\geq 8 \%$ mempunyai risiko 2,75 kali lebih besar mengalami perubahan tekanan darah ke arah hipotensi.

Hasil penelitian ini sama dengan penelitian Ferdi, R. (2015) menyatakan bahwa ada pengaruh tindakan hemodialisis terhadap perubahan tekanan darah pasien gagal ginjal kronis sebelum diberikan tindakan hemodialisis (pre test dan setelah diberikan hemodialisis (post test) terutama perubahan pada tekanan darah sistole.

Penelitian ini sedikit berbeda dengan penelitian yang dilakukan oleh Atsna (2016) dengan judul Hubungan Tingkat Kepatuhan Pengaturan Masukan Cairan Terhadap Tekanan Darah Pada Pasien Gagal Ginjal Kronis Yang menjalani Hemodialisis dimana hasil penelitian didapatka bahwa tidak terdapat hubungan antara kepatuhan manajemen masukan cairan terhadap tekanan darah pada pasien gagal ginjal kronik yang menjalani hemodialisis di RS PKU Muhamadiyah unit II Kota Yogyakarta. Hal ini dikarenakan banyak faktor yang menyebabkan perubahan tekanan darah pada pasien gagal ginjal kronik salah satunya adalah penggunaan obat. Obat antihipertensi menjaga tekanan darah sehingga mampu menghambat terjadinya perkembangan dari kerusakan ginjal lebih lanjut. Menurut penelitian Darnindro dan
Muthalib (2008) pasien dengan pemberian satu jenis obat tidak dapat mengendalikan tekanan darah sehingga ditambahkan obat antihipertensi dari golongan lain.

Upaya yang harus diperhatikan dan tindakan utama untuk membatasi intake cairan, adalah memonitoring dan memantau masukan cairan pada pasien yang menjalani hemodialisa dan melakukan pembatasan asupan cairan. Jika tidak dilakukan maka bisa menjadi salah satu pemicu terjadinya perubahan tekanan darah sistole/diastole.

Dalam melaksanakan penelitian ini, ada beberapa keterbatasan dari peneliti yaitu tidak diukurnya output cairan responden. Sementara output cairan akan mempengaruhi jumlah cairan yang tertahan di dalam tubuh responden. Untuk itu disarankan untuk peneliti selanjutnya menghitung intake dan output cairan responden sehingga balance cairan responden dapat diukur dengan baik.

\section{SIMPULAN DAN SARAN}

Dari penelitian diatas diketahui bahwa adanya perubahan tekanan darah pada pasien yang menjalani hemodialisis dan mayoritas perubahan bersifat positif/ meningkat baik tekanan darah sistole maupun diastole. Dan terdapatnya hubungan intake cairan dengan peningkatan tekanan darah sistole dan diastole.

Diharapkan hasil penelitian ini menjadi evidence based bagi perawat untuk membuat intervensi keperawatan pada pasien yang menjalani hemodialisa. Untuk peneliti selanjutnya diharapkan dapat menghitung intake cairan dengan dibarengi perhitungan output pasien, sehingga balance cairan dapat terukur.

\section{UCAPAN TERIMA KASIH}

Terima kasih peneliti ucapkan kepada seluruh staf dan karyawan RS Tingkat III Reksodiwiryo Padang 
khususnya kepada perawat di unit hemodialisa.

\section{DAFTAR PUSTAKA}

Abuelo, J. G. (1998). Large Interdialytic Weight Gain: Cause, Consequences, and Corrective Measures. Seminar in Dialysis. 11 (01). 25-32.

American kidney Foundation. Complication of CKD [internet]. 2016 [cited 2016 Dec 10]. Available from http://www.kidneyfund.org/kidneydisease/chronic-kidneydiseaseckd/complication/

Anggraini, Fany. (2016). Pemantauan Intake Output Cairan Pada Pasien Gagal Ginjal Kronik Dapat Mencegah Overload Cairan Diakses dari

http://repository.usu.ac.id/handle/123 $456789 / 27563$

Cianci, et al. (2009). Hypertension in Hemodialysis. An Overview on Physiopathology and Therapeutic Approach in Adults and Childrens. The Open Urology \& Nephrology Journal

Checheita IA, Turcu F,Dragomirescu RF, Ciocaiteu A. (2016). Chronic complication in Hemodialysis : correlations with Primary renaldisease. Romanian journal of Morphology, 51 (1), 2016

Darnindro N dan Muthalib A. (2008). Tatalaksana Hipertensi pada Pasien dengan Sindroma Nefrotik. Jurnal Kedokteran Indonesia

Fatmawati, I., \& Rahmawati, T. (2016). Hubungan Asupan Natrium dengan Tekanan Darah Pada Pasien Gagal Ginjal Kronik yang Menjalani Hemodialisis. Profesi (Profesional Islam): $\quad$ Media Publikasi Penelitian, 13(2).

Atsna Zafria. (2016). Hubungan tingkat kepatuhan manajemen masukan cairan terhadap tekanan darah pada pasien gagal ginjal kronik yang menjalani hemodialisa di $R S$ PKU Muhamadiyah Unit II Kota Yogyakarta.

Ferdi, R. (2015). Perubahan Tekanan Darah Pada Pasien Gagal Ginjal Kronis Sebelum Dan Setelah Menjalani Tindakan Hemodialisis Di Ruang Hemodialisa RSUD Dr. Ibnu Sutowo Baturaja: Baturaja

Mailani, Fitri. (2014). Hubungan penambahan Berat Badan Interdialisis dengan Kualitas Hidup Pasien Penyakit Ginjal Kronik yang Menjalani Hemodialisis. jurnal Riset Keperawatan Indonesia.vol.2.no.1. Januari-Juni 2014

Igbokwe, V.U. \& Obika, L.F.O. (2007). Thirst perception and dryness of mouth inhealthy young adults Nigerians. African Journal of Biomedical

Research.Vol.11http://www.ajbrui.c om/AJBR-111039046.pdf diunduh tanggal 6 Mei 2014.

Istanti, Y. P. (2013). Hubungan antara Masukan Cairan dengan Interdialytic Weight Gains (IDWG) pada Pasien Chronic Kidney Diseases di Unit Hemodialisis RS PKU Muhammadiyah Yogyakarta. Profesi (Profesional Islam): Media Publikasi Penelitian, 10(01).

Guyton, A.C. and Hall, J.E. (2006). Textbook of Medical Physiology. 11th ed. Philadelphia, PA, USA: Elsevier Saunders.

Lopez-Gomez, J. M.. (2005). Interdialytic Weight Gain as Marker of Blood Pressure, Nutrition, and Survival in Hemodialysis Patients. International Society of Nephrology. 67 (93), S63S68.

Lolyta, R.,Ismonah, Solechan. (2011). Analisis faktor yang mempengaruhi tekanan darah Hemodialisa pada 
klien gagal ginjal kronik. Diakses pada tanggal 9 Des 2015 dari http://ejournal.stikestelogorejo.ac.i d/ejournal/index.php/ilmukeperawa $\underline{\tan / \text { article }}$

National Kidney Foundation. About chronic kidney disease [internet]. National Kidney Foundation. (2016). [cited 2016 Dec 4]. Available from :

PERNEFRI. (2011). PERNEFRI: Indonesia

Proodjo, Sudjadi W, Suhardjono A. (2009). End-Stage Renal disease in Indonesia : treatment development. Ethnicity \& Disease. 19:33-6

Riskesdas. Riset Kesehatan Dasar (riskesdas) Indonesia [internet]. Indonesia;2013. Available from : http://depkes.go.id/resources/downl oad/general/Hasil Riskesdas 2012.pdf

Sarkar, S. R., Kotanko, P.,\& Levin, N. W. (2006). Interdialytic Weight Gain: Implications In Hemodialysis
Patients. Seminar in Dialysis : 19 (05), 429-433.

Smeltzer, S.C., Bare, B.G., Hinkle, J.L., \& Cheever, K.H. (2008). Textbook of Medical Surgical Nursing. 12 ed Philadelphia: Lippincott Williams \& Wilkins.

Sonnier, M.S., \& Bridget, L. (2000). Effect of self monitorinG and monetery reward on fluid adherence among adult hemodialysis patients. http://digital.library.unt.edu/ark:/675 31/metadc2693/m1/?q=Sonnier diakses pada tanggal 20 Desember 2013.

USRDS. United States Renal Data System (USRDS) [internet]. USRDS. Usrds.org/2016/view/Default.aspx

Widiyanto, P., Hadi, H., \& Wibowo, T. (2014). Korelasi Positif Perubahan Berat Badan Interdialisis dengan Perubahan Tekanan Darah Pasien Post Hemodialisa. Jurnal Ners dan Kebidanan Indonesia, 2(1), 1-8. 